Article

\title{
A New 9,10-Dihydrophenanthrene and Cell Proliferative 3,4-ס-Dehydrotocopherols from Stemona tuberosa
}

\author{
Yun-Seo Kil, Jiyoung Park, Ah-Reum Han, Hyun Ae Woo * and Eun-Kyoung Seo * \\ College of Pharmacy, Graduate School of Pharmaceutical Sciences, Ewha Womans University, \\ Seoul 120-750, Korea; E-Mails: k_yunseo@naver.com (Y.-S.K.); 37301012@hanmail.net (J.P.); \\ arhan@ewha.ac.kr (A.-R.H.) \\ * Authors to whom correspondence should be addressed; E-Mails: hawoo@ewha.ac.kr (H.A.W.); \\ yuny@ewha.ac.kr (E.-K.S.); Tel.: +82-2-3277-4654 (H.A.W.); +82-2-3277-3047 (E.-K.S.); \\ Fax: +82-2-3277-3760 (H.A.W.); +82-2-3277-3051 (E.-K.S.).
}

Academic Editor: Derek J. McPhee

Received: 9 February 2015 / Accepted: 30 March 2015 / Published: 3 April 2015

\begin{abstract}
A new compound, 9,10-dihydro-5-methoxy-8-methyl-2,7-phenanthrenediol (1), was isolated from the roots of Stemona tuberosa Lour. (Stemonaceae) together with two new optically active compounds, $\left(2 S, 4^{\prime} R, 8^{\prime} R\right)-3,4-\delta$-dehydrotocopherol (2) and $\left(2 R, 4^{\prime} R, 8^{\prime} R\right)-3,4-\delta$-dehydrotocopherol (3). The structures of compounds $\mathbf{1}-\mathbf{3}$ were determined on the basis of spectroscopic data analysis. Compounds $\mathbf{2}$ and $\mathbf{3}$ were each purified from a stereoisomeric mixture of $\mathbf{2}$ and $\mathbf{3}$ by preparative HPLC using a chiral column for the first time. The absolute configurations at C-2 of $\mathbf{2}$ and $\mathbf{3}$ were determined by Circular Dichroism (CD) experiments. As a part of the research to find natural wound healing agents, all isolates and the mixture of $\mathbf{2}$ and $\mathbf{3}$ were evaluated for their cell proliferative effects using a mouse fibroblast NIH3T3 and a HeLa human cervical cancer cell line. As a result, 1, 2, 3, or the mixture of 2 and 3 showed 41.6\%, 78.4\%, 118.6\%, $38.2 \%$ increases of cell proliferation in the mouse fibroblast NIH3T3 respectively, compared to $28.4 \%$ increase of $\delta$-tocopherol. Moreover, none of them induced cancer cell proliferation. Therefore, 3,4- $\delta$-dehydrotocopherols, especially pure isomers $\mathbf{2}$ and $\mathbf{3}$ can be suggested as potential wound healing agents.
\end{abstract}

Keywords: Stemona tuberosa; Stemonaceae; 9,10-dihydrophenanthrene; 3,4- $\delta$-dehydrotocopherol; chiral separation; cell proliferation 


\section{Introduction}

The dried root of Stemona tuberosa Lour. (Stemonaceae), known as Stemonae Radix, is called "back-bu-geun" in Korea. This herbal medicine was traditionally used as an antitussive and insecticidal drug in Asia [1]. Previous phytochemical reports on S. tuberosa mention alkaloids [2-5], stilbenoids [6,7], phenanthrene [7], and some minor dehydrotocopherol derivatives as isomer mixtures containing $\delta$-tocopherol [8]. The alkaloids and stilbenoids were reported as the antitussive [2-4] and antibacterial agents [7] while the dehydrotocopherol derivatives exhibited antioxidant activities [8].

In the general wound healing processes, fibroblasts play important roles in the replacement of damaged cells by synthesizing collagen proteins [9], so natural compounds found to induce cell proliferation in fibroblasts can be suggested as potential wound healing agent candidates.

In the present study, a new compound, 9,10-dihydro-5-methoxy-8-methyl-2,7-phenanthrenediol (1) was isolated from $S$. tuberosa, along with $\left(2 S, 4^{\prime} R, 8^{\prime} R\right)-3,4-\delta$-dehydrotocopherol (2) and $\left(2 R, 4^{\prime} R, 8^{\prime} R\right)$ 3,4- $\delta$-dehydrotocopherol (3) (Figure 1). Preparative HPLC using a chiral column was performed for the purification of compounds $\mathbf{2}$ and $\mathbf{3}$ from their stereoisomeric mixture. All isolates and the mixture of $\mathbf{2}$ and $\mathbf{3}$ were tested for their cell proliferation activities on NIH3T3 and HeLa cell lines. Herein, we describe the isolation and structure elucidation of $\mathbf{1}-\mathbf{3}$ and suggest potent wound healing agent candidates.

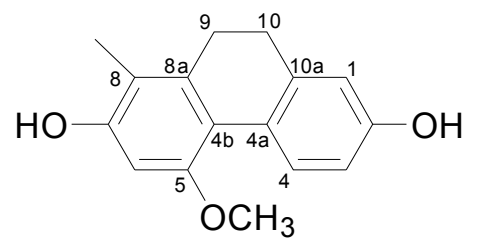

1

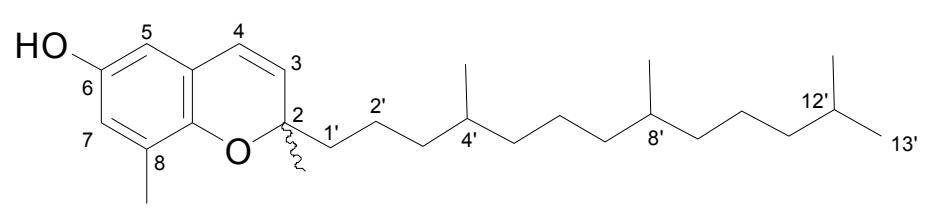

$22 S$

$32 R$

Figure 1. Chemical structures of the isolates 1-3 from the root of $S$. tuberosa.

\section{Results and Discussion}

\subsection{Structure Elucidation of Compound 1}

Compound 1 was isolated as a light brown oil and its molecular formula was assigned as $\mathrm{C}_{16} \mathrm{H}_{16} \mathrm{O}_{3}$ based on a protonated molecular ion peak at $\mathrm{m} / z 257.1172[\mathrm{M}+\mathrm{H}]^{+}\left(\right.$calcd. for $\left.\mathrm{C}_{16} \mathrm{H}_{17} \mathrm{O}_{3}, 257.1172\right)$ in HRESIMS. The ${ }^{1} \mathrm{H}$ - and ${ }^{13} \mathrm{C}-\mathrm{NMR}$ spectra of 1 exhibited four aromatic protons at $\delta \mathrm{H} 7.95(\mathrm{~d}, J=8.6 \mathrm{~Hz})$, $6.62(\mathrm{~d}, J=2.4 \mathrm{~Hz}), 6.59(\mathrm{dd}, J=8.6,2.4 \mathrm{~Hz})$, and $6.43(\mathrm{~s})$ with 12 aromatic carbons, indicating the presence of two aromatic rings in 1. Additionally, two methine groups appeared at $\delta_{\mathrm{H}} 2.66(2 \mathrm{H}, \mathrm{m}$, $\left.\mathrm{H}_{2}-9\right) / \delta \mathrm{c} 27.5$ and $2.60\left(2 \mathrm{H}, \mathrm{m}, \mathrm{H}_{2}-10\right) / 31.1$, which showed the COSY correlation between $\mathrm{H}_{2}-9$ and $\mathrm{H}_{2}-10$ and the HMBC cross peaks of $\mathrm{H}_{2}-9$ with $\mathrm{C}-8 / \mathrm{C}-4 \mathrm{~b}$ and $\mathrm{H}_{2}-10$ with $\mathrm{C}-1 / \mathrm{C}-4 \mathrm{a}$. With another important HMBC correlation of $\mathrm{H}-4$ with $\mathrm{C}-4 \mathrm{a}$, the above observations provided evidence of $\mathbf{1}$ being a 9,10-dihydrophenanthrene derivative [7,10]. The residual signals at $\delta_{\mathrm{H}} 3.78(3 \mathrm{H}, \mathrm{s})$ and $2.11(3 \mathrm{H}, \mathrm{s})$ were assignable to a methoxy group at $\mathrm{C}-5$ and a methyl group at $\mathrm{C}-8$ and the positions of these functionalities were confirmed by the $\mathrm{HMBC}$ correlations of $\mathrm{OCH}_{3}-5$ with $\mathrm{C}-5$ and $\mathrm{CH}_{3}-8$ with C-7/C-8/C-8a and NOESY cross peaks of $\mathrm{H}-1 / \mathrm{H}_{2}-10, \mathrm{OCH}_{3}-5 / \mathrm{H}-4$ and $\mathrm{H}-6$, and $\mathrm{CH}_{3}-8 / \mathrm{H}_{2}-9$ (Figure 2). The carbon resonances of two quaternary carbons at $\delta_{\mathrm{C}} 156.1(\mathrm{C}-2)$ and $155.4(\mathrm{C}-7)$ were indicative of 
the presence of hydroxy groups at $\mathrm{C}-2$ and $\mathrm{C}-7$. The unambiguous assignments of ${ }^{1} \mathrm{H}-$ and ${ }^{13} \mathrm{C}-\mathrm{NMR}$ resonances were conducted by further interpretations of the COSY, NOESY, HSQC, and HMBC data and by comparison of those with the literature values of the known compound, racemosol [7]. The only difference of 1 from the reported compound was the absence of a methoxy group at C-1. Therefore, the structure of 1 was elucidated a new compound, 9,10-dihydro-5-methoxy-8-methyl-2,7-phenanthrenediol.
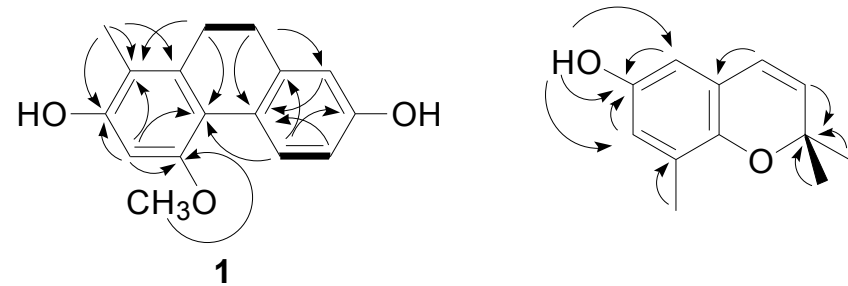

Figure 2. Key COSY $(-)$ and $\operatorname{HMBC}(\rightarrow)$ correlations of $\mathbf{1}$ and $\mathbf{2}$.

\subsection{Chiral Separation and Structure Determination of Compounds $\mathbf{2}$ and $\mathbf{3}$}

A subfraction was obtained by repeated column chromatography from the EtOAc extract of $S$. tuberosa. This subfraction appeared as a single peak in normal phase HPLC as described in the Experimental Section. However, the corresponding ${ }^{13} \mathrm{C}-\mathrm{NMR}$ spectrum showed overlapped peaks, which suggested that the subfraction was a mixture of isomers. This mixture was applied to a chiral column (ChiralPak IA, Daicel, Osaka, Japan, $5 \mu \mathrm{m}, 250 \times 10 \mathrm{~mm}$ ), and effectively separated by preparative HPLC to afford two pure stereoisomers, $2\left(t_{\mathrm{R}} 18.1 \mathrm{~min}, 15 \mathrm{mg}\right)$ and $\mathbf{3}\left(t_{\mathrm{R}} 21.1 \mathrm{~min}, 15 \mathrm{mg}\right)$ as shown in Figure 3.
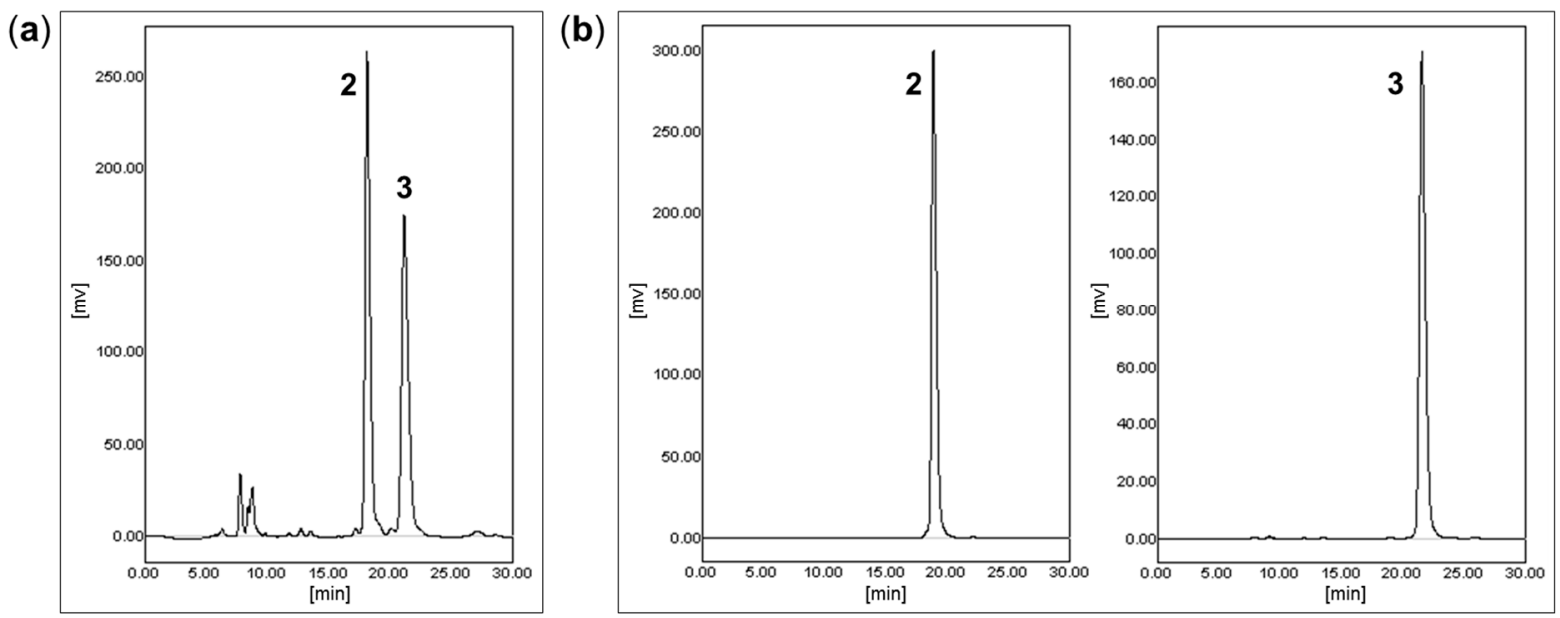

Figure 3. (a) HPLC chromatograms of mixture of 2 and 3; (b) HPLC chromatograms of pure isomers 2 and 3 [column: ChiralPak IA $(5 \mu \mathrm{m}, 250 \times 10 \mathrm{~mm})$; mobile phase: $n$-hexane-EtOH, 99:1, $v / v$; flow rate: $3 \mathrm{~mL} / \mathrm{min}$; detection: UV $265 \mathrm{~nm}$; $t_{\mathrm{R}}$ : (a) 2 18.1, $321.1 \mathrm{~min}$; (b) 2 18.8, $321.5 \mathrm{~min}]$.

Compounds 2 and 3 showed protonated HRESIMS molecular ion peaks at $\mathrm{m} / z 401.3412$ and 401.3416, respectively, corresponding to the same elemental formula of $\mathrm{C}_{27} \mathrm{H}_{44} \mathrm{O}_{2}$. The ${ }^{1} \mathrm{H}$ - and ${ }^{13} \mathrm{C}-\mathrm{NMR}$ data of both compounds were very similar to the reported values of $3,4-\delta$-dehydrotocopherol [8]. 
The planar structures of $\mathbf{2}$ and $\mathbf{3}$ were confirmed to correspond to 3,4- $\delta$-dehydrotocopherol by the detailed analysis of their HMBC and NOESY data (Figure 2). However, the ${ }^{1} \mathrm{H}-,{ }^{13} \mathrm{C}-\mathrm{NMR}$ data of 3 were slightly different from those of $\mathbf{2}$. The ${ }^{1} \mathrm{H}-\mathrm{NMR}$ spectrum of $\mathbf{3}$ was comparable with that of $\mathbf{2}$, except for the aliphatic protons of C-2' appearing at $\delta_{\mathrm{H}} 1.41(2 \mathrm{H}, \mathrm{m})$ in 3 instead of $\delta_{\mathrm{H}} 1.46$ and 1.36 (each $1 \mathrm{H}, \mathrm{m}$ ) in 2 . Two methyl groups, $\mathrm{CH}_{3}-4$ ' and $\mathrm{CH}_{3}-8$ ' resonated at $\delta_{\mathrm{H}} 0.834(6 \mathrm{H}, \mathrm{d}, J=6.4 \mathrm{~Hz})$ in 3 instead of $\delta_{\mathrm{H}} 0.841(3 \mathrm{H}, \mathrm{d}, J=6.4 \mathrm{~Hz})$ and $0.830(3 \mathrm{H}, \mathrm{d}, J=6.6 \mathrm{~Hz})$ in 2. Moreover, the carbon signals of $\mathrm{C}-1$ ' and $\mathrm{CH}_{3}-4$ ' in 3 appeared at $\delta_{\mathrm{C}} 40.97$ and 19.6 respectively, whereas they were observed at $\delta_{\mathrm{C}} 41.01$ and 19.7 in 2.

To solve the absolute configurations of $\mathbf{2}$ and $\mathbf{3}$, Circular dichroism (CD) experiments were performed. The Cotton effect of the 260-270 nm transition has been used to determine the absolute configurations of chiral centers near a styrene chromophore, and subgroups on the chromophore do not affect the sign of the Cotton effect [11]. The CD curve of $\mathbf{2}$ displayed a positive Cotton effect at 278 $\mathrm{nm}$ (as shown in Figure 4), thus the absolute configuration of C-2 was determined to be $S$ [12]. Conversely, a negative Cotton effect at $275 \mathrm{~nm}$ was shown in the CD data of 3 and the absolute configuration of C-2 was confirmed as $R$. As a result, the structures were assigned as $\left(2 S, 4^{\prime} R, 8^{\prime} R\right)-3,4-$ $\delta$-dehydrotocopherol (2) and $\left(2 R, 4^{\prime} R, 8^{\prime} R\right)-3,4-\delta$-dehydrotocopherol (3), respectively. This is the first report on the separation of $\mathbf{2}$ and $\mathbf{3}$ as optically active compounds, together with determination of the absolute configurations for both isomers.

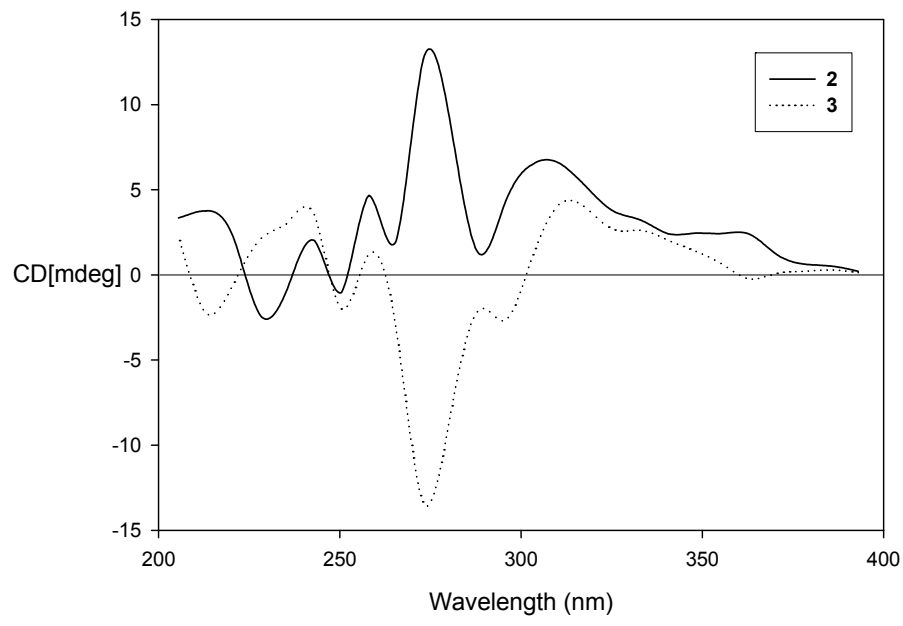

Figure 4. CD data of compounds 2 and 3.

\subsection{Cell Proliferative Effects}

The cell proliferation effects of all isolates and the mixture of $\mathbf{2}$ and $\mathbf{3}$ were evaluated on mouse fibroblasts NIH3T3 and human cervical cancer cells HeLa (Figure 5). In terms of chemical relevance with the tested compounds, $\delta$-tocopherol was used for comparison in the present biological study. Cells were treated with $10 \mu \mathrm{M}$ of all isolates, the mixture of $\mathbf{2}$ and $\mathbf{3}, \delta$-tocopherol, or DMSO alone and cell counts were performed every $24 \mathrm{~h}$. Daily microscopic examination of the cells showed no differences in cell attachment or morphology between compound-treated and control cells during the incubation times. As a result, all isolates or the mixture of $\mathbf{2}$ and $\mathbf{3}$ increased the number of NIH3T3 cells $(41.6 \%$, $78.4 \%, 118.6 \%$, or $38.2 \%$ respectively) compared to the DMSO-treated control cells after 4 days incubation with compounds. Incubation with $\delta$-tocopherol also led to a significant but smaller increase 
of NIH3T3 cells $(28.4 \%)$. Interestingly, none of these compounds had a proliferative effect on HeLa cells, indicating their ideal wound healing possibility.

(a)

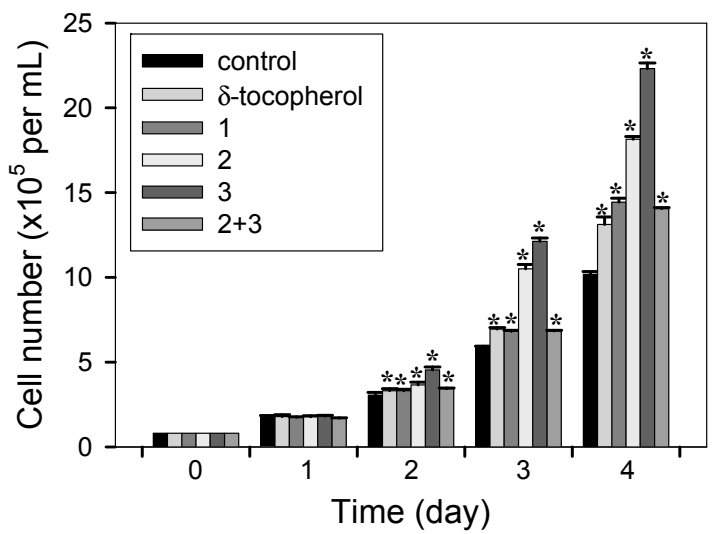

(b)

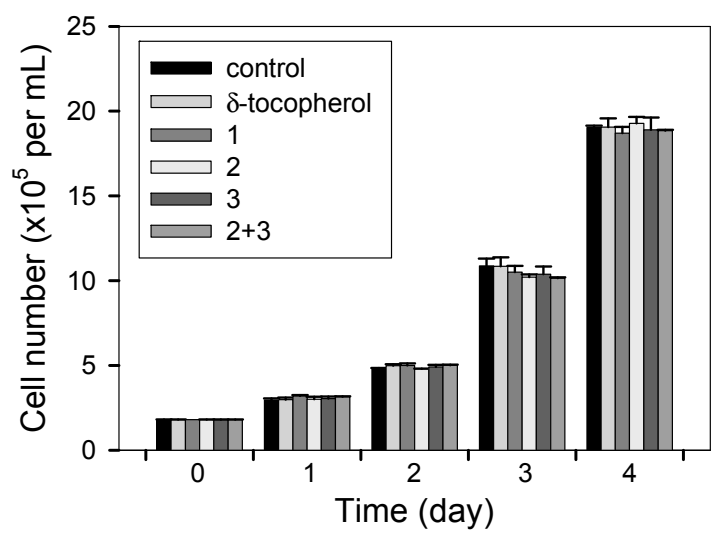

Figure 5. Cell proliferation activities of $\delta$-tocopherol, all isolates, or the mixture of $\mathbf{2}$ and $\mathbf{3}$ (a) on NIH3T3 cells and (b) on HeLa cells. Equal numbers of cells were treated with DMSO alone (control), $10 \mu \mathrm{M}$ of $\delta$-tocopherol, all isolates, or the mixture of $\mathbf{2}$ and $\mathbf{3}$ $(2+3)$ and cells were counted every $24 \mathrm{~h}$. Data represent the mean \pm s.d. of three independent experiments. ${ }^{*} p<0.05 v s$. control (DMSO alone).

The compounds promoted fibroblast growth dose-dependently. NIH3T3 cells were treated with the indicated concentrations of $\delta$-tocopherol, all isolates, and the mixture of 2 and 3 . After 4 days of incubation, cell numbers were counted. Growth promotion rates in NIH3T3 cells by $0.5,1,5$, and $10 \mu \mathrm{M}$ concentrations of compound 3 were $1.0 \%, 50.6 \%, 89.5 \%$, and $119.6 \%$, respectively $(* p<0.01 v s$. control) (Figure 6).

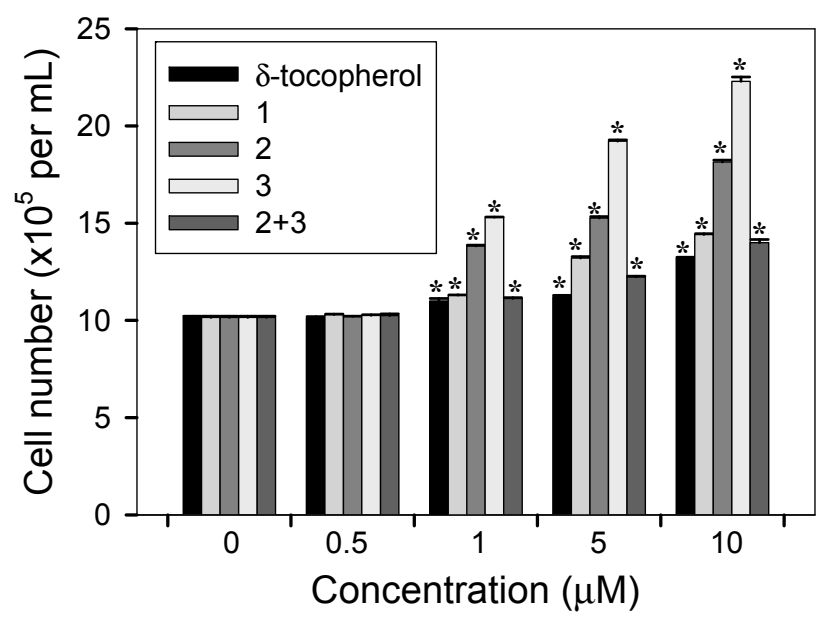

Figure 6. Dose-dependency of cell proliferation activities of $\delta$-tocopherol, all isolates, or the mixture of $\mathbf{2}$ and $\mathbf{3}$ on NIH3T3 cells. Equal numbers of cells were treated with DMSO alone (control), indicated concentrations of $\delta$-tocopherol, all isolates, or the mixture of 2 and $3(2+3)$ and cells growth was determined after 4 days by counting cell numbers. Data represent the mean \pm s.d. of three independent experiments. ${ }^{*} p<0.05 v s$. control $(0 \mu \mathrm{M})$. 
Similar dose-dependent growth promotion by compound 2 was also observed. Growth promotion rates in NIH3T3 cells by $0.5,1,5$, and $10 \mu \mathrm{M}$ concentrations of compound 2 were $0.5 \%, 35.7 \%$, $49.6 \%$, and $78.7 \%$, respectively ( $* p<0.01 v s$. control) Incubation with compounds 1 , the mixture of 2 and $\mathbf{3}$, and $\delta$-tocopherol also led to a significant but smaller dose-dependent growth promotion effect.

\section{Experimental Section}

\subsection{General Procedures}

$\delta$-Tocopherol was purchased from Sigma (St. Louis, MO, USA). Optical rotations were measured on a P-1010 polarimeter (Jasco, Tokyo, Japan). UV spectra were recorded on a U-3000 spectrophotometer (Hitachi, Tokyo, Japan). CD spectra were obtained using a J-810 CD-ORD spectropolarimeter (Jasco). HR-ESI mass spectrometric analyses were performed with a Waters ACQUITY UPLC system (Waters, Milford, MA, USA) coupled to a Micromass Q-Tof Micro mass spectrometer and Agilent 6220 Accurate-Mass TOF LC/MS system (Agilent, Santa Clara, CA, USA). The 1D and 2D NMR experiments were performed on a Unity Inova $400 \mathrm{MHz}$ FT-NMR instrument (Varian, Palo Alto, CA, USA) with tetramethylsilane (TMS) as an internal standard. Thin-layer chromatographic (TLC) analysis was performed on Kieselgel 60 F254 (Merck, Darmstadt, Germany), with visualization under UV light (254 and $365 \mathrm{~nm})$ and $10 \%(v / v)$ sulfuric acid spray followed by heating (120 ${ }^{\circ} \mathrm{C}$, $5 \mathrm{~min}$ ). Silica gel (230-400 mesh, Merck) and Sephadex LH-20 (GE Healthcare, Uppsala, Sweden) were used for column chromatography (CC). Preparative HPLC was carried out on an Acme 9000 system (Young Lin, Anyang, Korea) equipped with CHEMOSORB 5Si (5 $\mu \mathrm{m}, 250 \times 20 \mathrm{~mm}$,

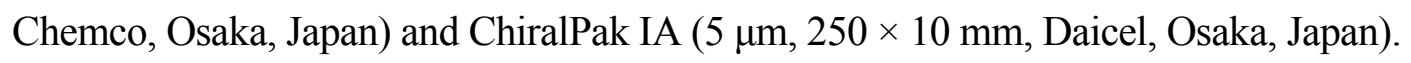

\subsection{Plant Material}

The dried roots of $S$. tuberosa were purchased from the Insan Oriental Herbal Market in Seoul, Korea. The sample was identified by Prof. Je-Hyun Lee (College of Oriental Medicine, Dongguk University, Gyeongju, Korea). A voucher specimen (No. EA322) has been deposited at the Natural Product Chemistry Laboratory, College of Pharmacy, Ewha Womans University (Seoul, Korea).

\subsection{Extraction and Isolation}

The roots of $S$. tuberosa $(10 \mathrm{~kg})$ were extracted with $\mathrm{MeOH}(3 \times 15 \mathrm{~L})$ overnight at room temperature. The solvent was evaporated in vacuo to afford a $\mathrm{MeOH}$ extract $(3.6 \mathrm{~kg})$, which was then suspended in distilled water, and successively partitioned with hexanes $(3 \times 5 \mathrm{~L})$, EtOAc $(6 \times 5 \mathrm{~L})$, and $n$-BuOH $(6 \times 5 \mathrm{~L})$. The EtOAc extract $(98 \mathrm{~g})$ was subjected to silica gel column chromatography $(\mathrm{CC})$ $\left(\mathrm{CH}_{2} \mathrm{Cl}_{2}-\mathrm{MeOH}, 100: 0\right.$ to $\left.0: 100, v / v\right)$ to obtain 12 fractions (F01-F12). F03 (0.5 g), eluted with $\mathrm{CH}_{2} \mathrm{Cl}_{2}-\mathrm{MeOH}$ (999:1) from the first separation, was subjected to Sephadex LH-20 CC (100\% $\mathrm{MeOH}$ ) to give six subfractions (F03.01-F03.06). Subfraction F03.03 (176 mg) was separated by preparative HPLC (CHEMOSORB 5Si, $n$-hexane-EtOAc, 9:1, v/v, $2 \mathrm{~mL} / \mathrm{min}, \mathrm{UV} 265,330 \mathrm{~nm}$ ) to yield an isomer mixture ( $t_{\mathrm{R}} 59.4 \mathrm{~min}, 92 \mathrm{mg}$ ). The isomer mixture was purified by chiral preparative HPLC (ChiralPak IA, $n$-hexane-EtOH, 99:1, v/v, $3 \mathrm{~mL} / \mathrm{min}$, UV $265 \mathrm{~nm})$ to afford compounds $2\left(t_{\mathrm{R}}\right.$ $18.8 \mathrm{~min}, 15 \mathrm{mg})$ and $3\left(t_{\mathrm{R}} 21.5 \mathrm{~min}, 15 \mathrm{mg}\right)$. F06 $(3.4 \mathrm{~g})$ was subjected to silica gel CC 
(hexanes-acetone, 5:1 to 1:1, v/v) to give 16 subfractions (F06.01-F06.16). Subfraction F06.14 (20 mg) was purified by preparative HPLC (CHEMOSORB 5Si, $\mathrm{CHCl}_{3}-\mathrm{MeOH}, 9: 1, v / v, 2 \mathrm{~mL} / \mathrm{min}$, UV 280, $300 \mathrm{~nm})$ to afford compound $1\left(t_{\mathrm{R}} 30.7 \mathrm{~min}, 7 \mathrm{mg}\right)$.

9,10-Dihydro-5-methoxy-8-methyl-2,7-phenanthrenediol (1). Light brown oil. UV (MeOH) $\lambda_{\max }(\log \varepsilon)$ 298 (2.98), 279 (3.13) nm; ${ }^{1} \mathrm{H}-$ and ${ }^{13} \mathrm{C}-\mathrm{NMR}$ data: see Table 1; HRESIMS $m / z$ 257.1172 [M+H] ${ }^{+}$ (calcd. for $\mathrm{C}_{16} \mathrm{H}_{17} \mathrm{O}_{3}{ }^{+}, 257.1172$ ).

Table 1. ${ }^{1} \mathrm{H}-\mathrm{NMR}(400 \mathrm{MHz})$ and ${ }^{13} \mathrm{C}-\mathrm{NMR}(100 \mathrm{MHz})$ data of compound $\mathbf{1}^{\mathrm{a}}$.

\begin{tabular}{ccc}
\hline No. & $\boldsymbol{\delta}_{\mathbf{H}}$ & $\boldsymbol{\delta}_{\mathbf{C}}$ \\
\hline 1 & $6.62, \mathrm{~d}(2.4)$ & 114.7 \\
2 & - & 156.1 \\
3 & $6.59, \mathrm{dd}(8.6,2.4)$ & 113.6 \\
4 & $7.95, \mathrm{~d}(8.6)$ & 130.4 \\
$4 \mathrm{a}$ & - & 126.7 \\
$4 \mathrm{~b}$ & - & 117.3 \\
5 & - & 156.8 \\
6 & - & 99.3 \\
7 & - & 155.4 \\
8 & - & 114.8 \\
$8 \mathrm{a}$ & - & $140.40^{\mathrm{b}}$ \\
9 & $2.66, \mathrm{~m}$ & 27.5 \\
10 & $2.60, \mathrm{~m}$ & 31.1 \\
$10 \mathrm{a}$ & - & $140.43^{\mathrm{b}}$ \\
$\mathrm{OCH}_{3}-5$ & $3.78, \mathrm{~s}$ & 56.1 \\
$\mathrm{CH}_{3}-8$ & $2.11, \mathrm{~s}$ & 11.6 \\
\hline${ }_{\mathrm{a}}$ in $\mathrm{CD}_{3} \mathrm{OD}, \delta$ in ppm, $J$ in Hz; ${ }^{\mathrm{b}}$ interchangeable.
\end{tabular}

(2S, 4'R, $\left.8^{\prime} R\right)-3,4-\delta$-Dehydrotocopherol (2). Brown oil. $[\alpha]_{D}^{25}+12\left(c\right.$ 0.1, EtOH); UV (MeOH) $\lambda_{\max }(\log \varepsilon)$ 332 (4.0), 272 (4.2), 264 (4.3), 230 (4.8); CD (MeOH, $\left.c=2.5 \times 10^{-3} \mathrm{M}\right) \Delta \varepsilon(\mathrm{nm})+23.3$ (278); ${ }^{1} \mathrm{H}-\mathrm{NMR}\left(\mathrm{CD}_{3} \mathrm{OD}, 400 \mathrm{MHz}\right) \delta 6.46(1 \mathrm{H}, \mathrm{d}, J=2.9 \mathrm{~Hz}, \mathrm{H}-7), 6.32(1 \mathrm{H}, \mathrm{d}, J=2.9 \mathrm{~Hz}, \mathrm{H}-5), 6.24(1 \mathrm{H}$, $\mathrm{d}, J=9.6 \mathrm{~Hz}, \mathrm{H}-4), 5.59(1 \mathrm{H}, \mathrm{d}, J=9.6 \mathrm{~Hz}, \mathrm{H}-3), 4.26(1 \mathrm{H}, \mathrm{s}, \mathrm{OH}), 2.13\left(3 \mathrm{H}, \mathrm{s}, \mathrm{CH}_{3}-8\right), 1.62(2 \mathrm{H}, \mathrm{m}$, H-1'), 1.52 (1H, m, H-12'), $1.46\left(1 \mathrm{H}, \mathrm{m}, \mathrm{H}_{\mathrm{a}}-2^{\prime}\right), 1.43-1.32\left(2 \mathrm{H}, \mathrm{m}, \mathrm{H}-4^{\prime}\right.$ and $\left.8^{\prime}\right), 1.36\left(1 \mathrm{H}, \mathrm{m}, \mathrm{H}_{\mathrm{b}}-2^{\prime}\right)$, $1.34\left(3 \mathrm{H}, \mathrm{s}, \mathrm{CH}_{3}-2\right), 1.32\left(1 \mathrm{H}, \mathrm{m}, \mathrm{H}_{\mathrm{a}}-6^{\prime}\right), 1.32-0.98\left(8 \mathrm{H}, \mathrm{m}, \mathrm{H}-3^{\prime}, 5^{\prime}, 7^{\prime}\right.$, and 9'), 1.27 (2H, m, H-10'), $1.15\left(1 \mathrm{H}, \mathrm{m}, \mathrm{H}_{\mathrm{b}}-6^{\prime}\right), 1.14\left(2 \mathrm{H}, \mathrm{m}, \mathrm{H}-11^{\prime}\right), 0.86\left(6 \mathrm{H}, \mathrm{d}, J=6.4 \mathrm{~Hz}, \mathrm{CH}_{3}-12^{\prime}\right.$ and $\left.\mathrm{H}_{3}-13^{\prime}\right), 0.841(3 \mathrm{H}, \mathrm{d}$, $J=6.4 \mathrm{~Hz}, \mathrm{CH}_{3}-8^{\prime}$ interchangeable with $\left.\mathrm{CH}_{3}-4{ }^{\prime}\right), 0.830\left(3 \mathrm{H}, \mathrm{d}, J=6.6 \mathrm{~Hz}, \mathrm{CH}_{3}-4\right.$ ', interchangeable with $\left.\mathrm{CH}_{3}-8^{\prime}\right) ;{ }^{13} \mathrm{C}-\mathrm{NMR}\left(\mathrm{CDCl}_{3}\right) \delta 148.5(\mathrm{C}-6), 145.0$ (C-8a), 131.1 (C-3), 126.4 (C-8), 122.7 (C-4), 121.5 (C-4a), 117.0 (C-7), 110.2 (C-5), 78.0 (C-2), 41.01 (C-1'), 39.4 (C-11'), 37.5 (C-3', interchangeable with C-5', C-7', or C-9'), 37.4 (C-5', interchangeable with C-3', C-7', or C-9'), 37.34 (C-7', interchangeable with C-3', C-5', or C-9'), 37.29 (C-9', interchangeable with C-3', C-5', or C-7'), 32.8 (C-8'), 32.7 (C-4'), 28.0 (C-12'), $25.8\left(\mathrm{CH}_{3}-2\right), 24.8$ (C-10'), 24.4 (C-6'), 22.7 ( $\left.\mathrm{CH}_{3}-12^{\prime}\right), 22.6$ (C-13'), 21.3 (C-2'), $19.8\left(\mathrm{CH}_{3}-8^{\prime}\right), 19.7\left(\mathrm{CH}_{3}-4^{\prime}\right), 15.5\left(\mathrm{CH}_{3}-8\right)$; HRESIMS m/z $401.3416[\mathrm{M}+\mathrm{H}]^{+}$ (calcd. for $\mathrm{C}_{27} \mathrm{H}_{45} \mathrm{O}_{2}, 401.3414$ ). 


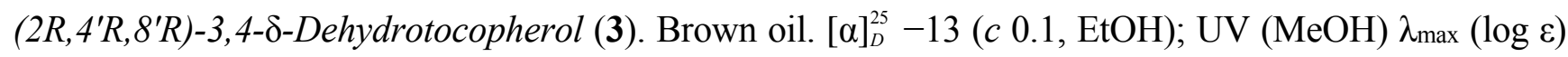
331 (3.9), 273 (4.1), 264 (4.2), 232 (4.8); $\mathrm{CD}\left(\mathrm{MeOH}, c=2.5 \times 10^{-3} \mathrm{M}\right) \Delta \varepsilon$ (nm) -20.3 (275); ${ }^{1} \mathrm{H}-\mathrm{NMR}\left(\mathrm{CD}_{3} \mathrm{OD}, 400 \mathrm{MHz}\right) \delta 6.47(1 \mathrm{H}, \mathrm{d}, J=3.2 \mathrm{~Hz}, \mathrm{H}-7), 6.32(1 \mathrm{H}, \mathrm{d}, J=3.2 \mathrm{~Hz}, \mathrm{H}-5), 6.24(1 \mathrm{H}$, $\mathrm{d}, J=9.8 \mathrm{~Hz}, \mathrm{H}-4), 5.58(1 \mathrm{H}, \mathrm{d}, J=9.8 \mathrm{~Hz}, \mathrm{H}-3), 4.27(1 \mathrm{H}, \mathrm{s}, \mathrm{OH}), 2.13\left(3 \mathrm{H}, \mathrm{s}, \mathrm{CH}_{3}-8\right), 1.61(2 \mathrm{H}, \mathrm{m}$, H-1'), 1.52 (1H, m, H-12'), 1.41 (2H, m, H2-2'), 1.42-1.32 (2H, m, H-4' and 8'), 1.34 (3H, s, $\left.\mathrm{CH}_{3}-2\right)$, $1.32\left(1 \mathrm{H}, \mathrm{m}, \mathrm{H}_{\mathrm{a}}-6^{\prime}\right), 1.32-0.98\left(8 \mathrm{H}, \mathrm{m}, \mathrm{H}-3^{\prime}, 5^{\prime}, 7^{\prime}\right.$, and 9'), $1.26\left(2 \mathrm{H}, \mathrm{m}, \mathrm{H}-10^{\prime}\right), 1.16\left(1 \mathrm{H}, \mathrm{m}, \mathrm{H}_{\mathrm{b}}-6^{\prime}\right)$, $1.14\left(2 \mathrm{H}, \mathrm{m}, \mathrm{H}-11^{\prime}\right), 0.86\left(6 \mathrm{H}, \mathrm{d}, J=6.4 \mathrm{~Hz}, \mathrm{CH}_{3}-12^{\prime}\right.$ and $\left.\mathrm{H}_{3}-13^{\prime}\right), 0.834\left(3 \mathrm{H}, \mathrm{d}, J=6.4 \mathrm{~Hz}, \mathrm{CH}_{3}-8^{\prime}\right.$ and $\left.\mathrm{CH}_{3}-4{ }^{\prime}\right) ;{ }^{13} \mathrm{C}-\mathrm{NMR}\left(\mathrm{CDCl}_{3}\right) \delta 148.5(\mathrm{C}-6), 145.0(\mathrm{C}-8 \mathrm{a}), 131.1(\mathrm{C}-3), 126.4(\mathrm{C}-8), 122.7$ (C-4), 121.5 (C-4a), 117.0 (C-7), 110.2 (C-5), 78.0 (C-2), 40.97 (C-1'), 39.4 (C-11'), 37.4 (C-3', interchangeable with C-5', C-7', or C-9'), 37.4 (C-5', interchangeable with C-3', C-7', or C-9'), 37.34 (C-7', interchangeable with C-3', C-5', or C-9'), 37.35 (C-9', interchangeable with C-3', C-5', or C-7'), 32.8 (C-8'), 32.7 (C-4'), 28.0 (C-12'), 25.8 ( $\left.\mathrm{CH}_{3}-2\right), 24.8$ (C-10'), 24.5 (C-6'), $22.7\left(\mathrm{CH}_{3}-12^{\prime}\right), 22.6$ (C-13'), $21.3\left(\mathrm{C}^{2} 2^{\prime}\right), 19.8\left(\mathrm{CH}_{3}-8^{\prime}\right), 19.6\left(\mathrm{CH}_{3}-4^{\prime}\right), 15.5\left(\mathrm{CH}_{3}-8\right)$; HRESIMS $m / z 401.3412[\mathrm{M}+\mathrm{H}]^{+}$(calcd. for $^{2}$ $\left.\mathrm{C}_{27} \mathrm{H}_{45} \mathrm{O}_{2}, 401.3414\right)$.

\subsection{Cell Culture}

The mouse fibroblasts NIH3T3 and HeLa human cervical cancer cells were obtained from the American Type Culture Collection (Manassas, VA, USA). The NIH3T3 cells displayed fibroblastic morphology and HeLa cells were polygonal. Both cells were tightly adherent to the flask, and were highly proliferative. NIH3T3 cells were cultured in Dulbecco's Modified Eagle's Medium (DMEM, Welgene, Gyeongsan, Korea) supplemented with 10\% bovine calf serum (HyClone, Logan, UT, USA) and $1 \%$ penicillin-streptomycin (HyClone), HeLa cells were maintained in DMEM supplemented with $10 \%$ fetal bovine serum (HyClone) and $1 \%$ penicillin-streptomycin. Cells were maintained at $37{ }^{\circ} \mathrm{C}$ with $5 \% \mathrm{CO}_{2}$ in a humidified atmosphere. The cells were subcultured when $80 \%$ confluence was reached according to the manufacturer's recommendation. The morphology of the cells was examined under a microscope.

\subsection{Cell Proliferation Assay}

For proliferation studies, cell number count was conducted in monolayer culture in 12-well culture plates using a hemocytometer. NIH3T3 or HeLa cells were seeded at an initial density of $1 \times 10^{5}$ cells per $\mathrm{mL}$ medium containing DMSO only, $10 \mu \mathrm{M}$ of all isolates, the mixure of $\mathbf{2}$ and $\mathbf{3}$, or $\delta$-tocopherol. Cells were trypsinized and then viable cell numbers were counted in triplicates for each group every $24 \mathrm{~h}$. The data was recorded as the average of three independent experiments. For the dose-dependency of cell proliferative effects of compounds, NIH3T3 cells were seeded at an initial density of $1 \times 10^{5}$ cells per mL medium containing all isolates, the mixture of $\mathbf{2}$ and $\mathbf{3}$, or $\delta$-tocopherol $(0.5 \mu \mathrm{M}-10 \mu \mathrm{M}$; control DMSO only) and the effect on cell growth was determined after 4 days by counting cell numbers. Cell numbers were counted in triplicate for each group, and three independent experiments were performed. 


\subsection{Statistical Analysis}

All results were expressed as mean \pm s.d. Student's $t$-test was used for comparisons involving two groups. $p<0.05$ was considered to indicate a statistically significant difference.

\section{Conclusions}

In the present phytochemical study, a new compound, 9,10-dihydro-5-methoxy-8-methyl-2,7phenanthrenediol (1) was isolated from the roots of $S$. tuberosa Lour. The structure of 1 was elucidated by the interpretation of its spectroscopic data. In addition, $\left(2 S, 4^{\prime} R, 8^{\prime} R\right)-3,4-\delta$-dehydrotocopherol (2) and $\left(2 R, 4^{\prime} R, 8^{\prime} R\right)-3,4-\delta$-dehydrotocopherol (3) were separated for the first time from the stereoisomeric mixtures of $\mathbf{2}$ and $\mathbf{3}$ by preparative HPLC using a chiral column. CD experiments were utilized to determine the absolute configurations at $\mathrm{C}-2$ of $\mathbf{2}$ and $\mathbf{3}$. When all isolates and the mixture of $\mathbf{2}$ and $\mathbf{3}$ were evaluated for their cell proliferative effects, the pure isomers $\mathbf{2}$ and $\mathbf{3}$ exhibited remarkable effects, suggesting the two compounds as powerful wound healing agent candidates.

\section{Supplementary Materials}

Supplementary materials can be accessed at: http://www.mdpi.com/1420-3049/20/04/5965/s1.

\section{Acknowledgments}

This research was supported by the Basic Science Research Program through the National Research Foundation of Korea (NRF) funded by the Ministry of Science, ICT and Future Planning (MSIF) (NRF-2013R1A2A2A01067336).

\section{Author Contributions}

Eun-Kyoung Seo and Hyun Ae Woo conceived and designed the experiments; Yun-Seo Kil and Jiyoung Park performed the experiments; Yun-Seo Kil, Jiyoung Park, Ah-Reum Han, Hyun Ae Woo, and Eun-Kyoung Seo analyzed the data and wrote the paper.

\section{Conflicts of Interest}

The authors declare no conflict of interest.

\section{References}

1. Bensky, D.; Gamble, A. Chinese Herbal Medicine: Materia Medica, revised ed.; Eastland Press: Seattle, WA, USA, 1993; pp. 202-203.

2. Lin, L.-G.; Leung, H.P.; Zhu, J.-Y.; Tang, C.-P.; Ke, C.-Q.; Rudd, J.A.; Lin, G.; Ye, Y. Croomine- and tuberostemonine-type alkaloids from roots of Stemona tuberosa and their antitussive activity. Tetrahedron 2008, 64, 10155-10161. 
3. Xu, Y.-T.; Hon, P.-M.; Jiang, R.-W.; Cheng, L.; Li, S.-H.; Chan, Y.-P.; Xu, H.-X.; Shaw, P.-C.; But, P.P. Antitussive effects of Stemona. tuberosa with different chemical profiles. J. Ethnopharmacol. 2006, 108, 46-53.

4. Chung, H.-S.; Hon, P.-M.; Lin, G.; But, P.P.; Dong, H. Antitussive activity of Stemona alkaloids from Stemona tuberosa. Planta Med. 2003, 69, 914-920.

5. Kil, Y.-S.; Han, A.-R.; Seo, E.K. Tuberostemonine O from the roots of Stemona tuberosa. Bull. Korean Chem. Soc. 2014, 35, 1891-1893.

6. Lin, L.-G.; Yang, X.-Z.; Tang, C.-P.; Ke, C.-Q.; Zhang, J.-B.; Ye, Y. Antibacterial stilbenoids from the roots of Stemona tuberosa. Phytochemistry 2007, 69, 457-463.

7. Khamko, V.A.; Quang, D.N.; Dien, P.H. Three new phenanthrenes, a new stilbenoid isolated from the roots of Stemona tuberosa Lour and their cytotoxicity. Nat. Prod. Res. 2013, 27, 2328-2332.

8. Brem, B.; Seger, C.; Pacher, T.; Hartl, M.; Hadacek, F.; Hofer, O.; Vajrodaya, S.; Greger, H. Antioxidant dehydrotocopherols as a new chemical character of Stemona species. Phytochemistry 2004, 65, 2719-2729.

9. Clark, R.A. Biology of dermal wound repair. Dermatol. Clin. 1993, 11, 647-666.

10. Zhang, Y.-Z.; Xu, G.-B.; Zhang, T. Antifungal stilbenoids from Stemona japonica. J. Asian Nat. Prod. Res. 2008, 10, 634-639.

11. Crabbe, P. Cotton effect of the styrene chromophore. Chem. Ind. 1969, 917-918.

12. Kikuchi, T.; Mori, Y.; Yokoi, T.; Nakazawa, S.; Kuroda, H.; Masada, Y.; Kitamura, K.; Kuriyama, K. Structure and absolute configuration of sagatriol, a new isoprenoid chromenol from a brown alga, Sargassum tortile C. AGARDH. Chem. Pharm. Bull. 1983, 31, 106-113.

Sample Availability: Not available.

(C) 2015 by the authors; licensee MDPI, Basel, Switzerland. This article is an open access article distributed under the terms and conditions of the Creative Commons Attribution license (http://creativecommons.org/licenses/by/4.0/). 